 \\ z Filologii Polskiej \\ i Słowiańskiej
}

\author{
Małgorzata Korytkowska \\ (Instytut Slawistyki Polskiej Akademii Nauk, Warszawa)
}

\section{Czasowniki mentalne i czasowniki emocji w opisie semantyczno-syntaktycznym}

1. Objęcie analizą semantyczno-syntaktyczną klas czasowników określanych na podstawie cech semantycznych wiąże się z koniecznością sprecyzowania kryteriów, zgodnie z którymi wyznacza się granice klas, a co się z tym wiąże - z koniecznością określenia stopnia szczegółowości uwzględnianych cech. W tym artykule uwaga skupiona jest na klasach verba cogitandi (mentalis) oraz verba sentiendi, zaliczanych nieraz w literaturze językoznawczej do szerszej klasy czasowników „psychicznych” lub „stanów wewnętrznych”. Szerzej rozumiany termin „predykaty / czasowniki psychiczne” obejmuje jednostki odnoszące się do sfery intelektualnej, uczuciowej oraz wolitywnej (por. też Jordanskaja, 1972; Nowakowska-Kempna, 1986). Skupienie się na dwóch wymienionych klasach wydaje się więc uzasadnione, zwłaszcza jeśli celem jest zasygnalizowanie cech przyjętego modelu badania oraz prześledzenie jego efektywności w zakresie opisu właściwości jednostek predykatywnych na poziomie syntaktycznym i wskazania ujawniających się na tym poziomie różnic między obydwoma zbiorami czasowników.

This is an Open Access article distributed under the terms of the Creative Commons Attribution 3.0 PL License (creativecommons.org/licenses/by/3.0/pl/), which permits redistribution, commercial and non-commercial, provided that the article is properly cited. ( ) The Author(s) 2017.

Publisher: Institute of Slavic Studies, Polish Academy of Sciences

[Wydawca: Instytut Slawistyki Polskiej Akademii Nauk] 
Przedstawiana w artykule problematyka wiąże się z pracami, które mają na celu badanie relacji między płaszczyzną semantyczną i formalną (zdaniową) oraz sformułowanie wniosków o zachodzących procesach i stopniu ich regularności w poszczególnych językach reprezentujących trzy podstawowe grupy języków słowiańskich oraz wniosków konfrontatywnych ${ }^{1}$. Biorąc pod uwagę objętość tego tekstu, ograniczono się jedynie do zarysowania problematyki teoretycznej i przykładowych wniosków wynikających z badania, a zjawiska zilustrowano przykładami z języka polskiego.

2. Podstawowym teoretycznym wzorem opisu zastosowanym w badaniu jest model składni semantycznej, sformułowany przez S. Karolaka (Karolak, 1984). Przy tworzeniu podstawowych struktur predykatowo-argumentowych (PSPA) uwzględnia się w tym modelu semantyczno-syntaktyczne cechy predykatów, przy czym przez te cechy autor rozumie „liczbę otwieranych przez nie pozycji dla argumentów oraz semantyczne właściwości argumentów zajmujących te pozycje" (Karolak, 1984, s. 53). Trzeba tu podkreślić, że autor miał świadomość ograniczeń wiążących się z tego typu rozstrzygnięciem i tym, że tworzenie pełnej parafrazy analitycznej (dekompozycji sensu) jest pewnym ideałem, który mógłby zapewnić adekwatny opis semantyczno-syntaktyczny, jednak opis taki musiałby wykorzystywać rozbudowany aparat analizy semantycznej, który byłby pozbawiony subiektywnych rozstrzygnięć. Uwzględniając więc we wzorcach PSPA pozycje powierzchniowo realizowane, S. Karolak przyjmuje zasadę ograniczania się do pozycji implikowanych przez czasownik, a podstawę procedury stanowi test wykazujący brak implikacji danego składnika, kiedy jego usunięcie powoduje asemantyczność lub zmienia sens wyrażenia (Karolak, 1984, ss. 55-56).

2.1. Klasy, których dotyczy badanie, nie wyróżniają się formalnie, dlatego też kryteria wyznaczające te zbiory muszą mieć charakter semantyczny. Współcześnie istnieje już wiele prac, w których parafraza analityczna lub inne techniki określania cech semantycznych leksemów stosowane są jako podstawowy aparat badania. Dotyczy to także obu omawianych w tym tekście klas czasowników. Poniżej zostały zarysowane podstawy opisu zawarte w pracach

1 Artykuł został przygotowany w ramach realizacji projektu naukowo-badawczego „Właściwości składniowe czasowników jako baza ich zintegrowanego opisu leksykograficznego (w perspektywie konfrontacji polsko-bułgarsko-rosyjskiej)" przyznanego na lata 2014-2017 przez Narodowe Centrum Nauki RP (nr grantu: 2013/11/B/HS2/03116). 
M. Danielewiczowej, I. Nowakowskiej-Kempnej oraz L. Jordanskiej, które - jako niesprzeczne teoretycznie z przyjętym w tym opracowaniu modelem opisu dostarczają wielu istotnych dla dalszej analizy wniosków (por. Danielewiczowa, 2002; Jordanskaja, 1972; Nowakowska-Kempna, 1986).

2.1.1. W monografii poświęconej czasownikom epistemicznym (mentalnym) M. Danielewiczowa ustala elementy, które jako obligatoryjne (definicyjne) występują w strukturach semantycznych predykatów mentalnych i mają charakter jednostek prostych (dalej nierozkładalnych semantycznie, w odróżnieniu od pozostałych, złożonych jednostek). Należy do nich predykat wiedzy, którego obecność autorka wykazuje w szczegółowej analizie zbioru 25 czasowników. Predykat ten otwiera pozycję argumentową dla podmiotu epistemicznego (PE) oraz pozycję dla argumentu odnoszącego się do sądu formułowanego przez podmiot epistemiczny. Do szczegółowej analizy w ramach tego badania zastosowany został pogłębiony aparat oparty na interpretacji struktur semantycznych badanych jednostek na podstawie wykazywanej dla każdej z nich struktury tematów i rematu, co posłużyło do wykazania obecności i usytuowania predykatu wiedzy, a ponadto pozwoliło na uwidocznienie różnic semantycznych między poszczególnymi jednostkami. Subkategoryzacja badanego zbioru czasowników epistemicznych (niezdarzeniowych i nieczynnościowych) opiera się na kryteriach, które dotyczą charakteru funkcji wyrażanej przez czasownik (stan vs zdarzenie). Zdarzenia obejmują klasę jednostek całkowicie niezależnych od działań podmiotu epistemicznego (PE) (np. domyślać się, uwierzyć) oraz klasę nimi uwarunkowaną. W strukturach predykatów niezdarzeniowych M. Danielewiczowa wyróżnia zbiory jednostek czynnościowych (obecność komponentu wskazującego na występowanie „czynności intelektualnej”) oraz nieczynnościowych. Dalsza subkategoryzacja zbioru czasowników nieczynnościowych opiera się na kryteriach dotyczących treści wyrażonej w ramach argumentu predykatywnego w kategoriach faktywności / niefaktywności, oceniającego / nieoceniającego charakteru jednostek, charakteru wiedzy (dostępna / niedostępna) czy wreszcie stosunku podmiotu epistemicznego do weryfikacji swojego stanu wiedzy. Sklasyfikowane zostały typy informacji o charakterze wiedzy, która zawarta jest w strukturze badanych czasowników. Wyróżnia się tu informację o wiedzy obecnej (dostępnej podmiotowi epistemicznemu, pochodzącej z danych zmysłowych, $\mathrm{z}$ wiedzy „wewnętrznej” oraz wnioskowania - por. wydawać się ... vs przeczuwać, $\dot{z} e$... vs wnioskować, że ...) lub informację wykraczającą poza wiedzę (wierzyć, że ...). 
Sklasyfikowane zostały również typy nastawienia PE - wyróżniono tu klasę jednostek, w których nastawienie jest obecne (z podklasami z występującym nastawieniem na weryfikację oraz z brakiem informacji o takim nastawieniu) oraz klasę, w której brak informacji o takim nastawieniu.

Podsumowując ten krótki zarys zastosowanych kryteriów analizy zawartej w monografii M. Danielewiczowej, można zauważyć, że opis i kryteria klasyfikacyjne skupione są na warstwie semantycznej, która została wszechstronnie i wnikliwie zanalizowana. Zasadniczo nie bada się odniesienia cech poziomu semantycznego do poziomu formalnego, a więc refleksów wyodrębnionych cech semantycznych na poziomie struktur zdaniowych. Wyjątek stanowi wyróżnienie w zbiorze jednostek niezdarzeniowych i nieczynnościowych podzbioru czasowników ze zdaniowo realizowanym argumentem propozycjonalnym oraz otwierających pozycję dla argumentu wyrażanego poprzez predykatywną frazę nominalną. Warto tu zaznaczyć, że według autorki zdania zawierające nominalizacje są różne semantycznie od zdań zawierających zdanie intensjonalne (por. Danielewiczowa, 2002, ss. 29-31). Wiele $\mathrm{z}$ cech stanowiących kryteria subkategoryzacji wyrażanych jest jedynie poprzez temat czasowników i ujawnia się w analizie ich relacji do innych jednostek zbioru, ewentualnie w analizie dopuszczalności / niedopuszczalności szerszych kontekstów (np. jednostka może selekcjonować podzbiory adwerbiów - por. * wgłębiać się $w$ coś powierzchownie).

2.1.2. Szczególnie ważne dla wiedzy o cechach klasy czasowników emocji, także ze względu na stosowany aparat analizy, są prace I. Nowakowskiej-Kempnej (Nowakowska-Kempna, 1986) oraz L. Jordanskiej (Jordanskaja, 1972). Monografia I. Nowakowskiej-Kempnej zawiera analizę predykatów uczuć ukierunkowaną na problematykę semantyczną oraz na kwestie związane $\mathrm{z}$ realizacją cech semantycznych $\mathrm{w}$ strukturze zdaniowej oraz ze zjawiskami, które $\mathrm{z}$ nich wynikają dla funkcjonowania tych predykatów w szerszych kontekstach. Propozycje L. Jordanskiej dotyczące kryteriów opisu klasy tych predykatów również odnoszą się do warstwy semantycznej.

W badaniach nad strukturą semantyczną predykatów uczuć do elementów obligatoryjnych zalicza się sytuację, która wywołuje uczucie (źródło, przyczynę powstania / doznawania uczucia), i lokalizatora uczucia / podmiotu doznania. Sytuacja wywołująca uczucie określana jest jako zdarzenie, które ma charakter czynności lub stanu. Zwraca się również uwagę na to, że w znaczeniu każdej jednostki występuje także charakterystyka stanu emocjonalnego, która zawiera ocenę (sąd wartościujący - pozytywny / negatywny - związany 
z postawą wolitywną) oraz cechę aktywności / pasywności (wymagającą / niewymagającą przejawiania się w zachowaniu) (por. Jordanskaja, 1972, s. 107; Nowakowska-Kempna, 1986, ss. 53, 78, 82). Szczególnego podkreślenia wymaga tu ustalenie, że struktura semantyczna predykatów uczuć charakteryzuje się relacją przyczynową - zdaniem Jordanskiej w słownikach z reguły wyrazy oznaczające uczucia definiowane są poprzez charakterystykę wewnętrzną uczucia oraz wskazanie przyczyny, która taki stan wywołuje (Jordanskaja, 1972, s. 106). W takim ujęciu punktem wyjścia analizy jest właśnie poziom semantycznej struktury elementarnej, przedstawianej jako rodzaj eksplikacji bądź też wyliczenia cech. Poziom ten stanowi podstawę dla interpretacji struktur syntaktycznych w kategoriach predykatowo-argumentowych. Na poziomie eksplikacyjnym obligatoryjnie występują są elementy, które I. Nowakowska-Kempna uważa za najważniejsze w hierarchii i jest to składnik x (Experiencer $-\mathrm{z}$ cechami [+Hum] lub [+Anim]) oraz relacja czuć otwierająca pozycję dla argumentu wskazującego przyczynę / źródło uczucia - por. x czuje coś. (Nowakowska-Kempna, 1986, ss. 21, 54, 135)².

2.1.3. Zarówno I. Nowakowska-Kempna, jak i L. Jordanskaja ustalają, że podstawową dychotomią dla klasy uczuć jest podział na afekty vs postawy, to znaczy nastroje i usposobienia w postaci dyspozycji do określonych zdarzeńafektów. Podstawową różnicę semantyczną między obydwiema klasami I. Nowakowska-Kempna upatruje w tym, że o ile uczucia-afekty implikują wystąpienie zdarzenia, które podlega sądowi wartościującemu, o tyle uczuciapostawy stanowią jedynie dyspozycje do określonych zdarzeń (jako sytuacji prowadzącej do zaistnienia afektu i relacji doznania) (Nowakowska-Kempna, 1986, s. 53). Zdarzeniowy charakter afektów sprawia, że są one lokalizowane na osi czasu w odróżnieniu od postaw emocjonalnych, które są stanami i cechuje je znaczenie nieaktualne. Zdaniem I. Nowakowskiej-Kempnej ta różnica przejawia się na poziomie zdaniowym poprzez różnice w dystrybucji operatorów więzi ze zdaniem realizującym argument propozycjonalny: $\dot{z} e$ wprowadza go po leksemach - afektach, jak / gdy / kiedy - po leksykalnych wykładnikach dyspozycji (Nowakowska-Kempna, 1986, s. 32). Por. np. Piotr cieszy się, że Jurek przyjechat. vs Lubię, jak Andrzej dzwoni do mnie. Cechą formalną wynikającą $\mathrm{z}$ aktualności - nieaktualności jest cecha formalna frazy - efektu nominalizacji

${ }^{2}$ Relacja przyczynowa jako obligatoryjny element struktur semantycznych predykatów emocji wskazywana jest w analizach zarówno językoznawczych, jak i psychologicznych. 
argumentu przyczyny, a więc występowanie liczby mnogiej frazy (realizowanej przez nomen actionis) w przypadkach, kiedy predykat odnosi się do dyspozycji (fraza ta ma wartość ogólną), por. np. Lubię, gdy Renia przychodzi na plotki. vs Lubię wizyty / odwiedziny Reni ( ${ }^{*}$ Lubię wizytę Reni.). Jednocześnie zarówno L. Jordanskaja, jak i I. Nowakowska-Kempna zauważają, że te same jednostki leksykalne (np. czasowniki) mogą wyrażać nie tylko afekty, lecz także dyspozycje (postawy), por. np. Boję się tego psa. - Boję się tygrysów. (por. Jordanskaja, 1972, s. 109; Nowakowska-Kempna, 1986, ss. 17-35).

2.1.4. Autorzy opracowań lingwistycznych, filozoficznych i psychologicznych podkreślają, że treść doznania, a więc także charakterystyka stanów (zdarzeń) emocjonalnych, dyferencjująca ich poszczególne rodzaje, jest bardzo trudna do przeprowadzenia (Jordanskaja, 1972, s. 107) lub nie podlega analizie (Nowakowska-Kempna, 1986, ss. 72-73), dlatego też definiuje się je głównie poprzez opisy sytuacji, które są ich rezultatem / poprzez zapis relewantnych objawów. Z tych samych powodów nie można analizować relacji między eksperiencerem a treścią jego doznania (Nowakowska-Kempna, 1986, s. 72).

Klasyfikacja zbioru uczuć-afektów dokonywana jest w referowanych tu pracach na podstawie następujących cech - kryteriów:

- tzw. ton uczuciowy - jakość uczucia jako stan pozytywny (przyjemny) / negatywny (nieprzyjemny), będący efektem różnych postaci nastawienia wolitywnego, który jest elementem wartościującym (Jordanskaja wyróżnia „pożądaność” jako element opinii o zdarzeniu-przyczynie stanu [por. Jordanskaja, 1972, s. 112; por. też Nowakowska-Kempna, 1986, ss. 135-136, 148]). Z tą cechą należy wiązać tzw. sąd wartościujący zdarzenie będące źródłem / przyczyną uczucia w kategoriach dobra - zła (NowakowskaKempna, 1986, ss. 137-150);

- aktywny / pasywny charakter przeżycia (por. np. pary: radość vs przyjemność, gniew vs przykrość). I. Nowakowska-Kempna umieszcza tę cechę w eksplikacjach sensu, np. $x$ czuje coś pasywnie $-x$ czuje coś aktywnie (Jordanskaja, 1972, s. 107; Nowakowska-Kempna, 1986, ss. 54, 156);

- zaistnienie zdarzenia (przyczyny) vs przypuszczalne / możliwe jego zaistnienie. L. Jordanskaja formułuje to jako stopień pewności wydarzenia B - przyczyny stanu emocjonalnego. Tak np. nadzieja i strach są stanami, dla których B jest wysoce prawdopodobne (Jordanskaja, 1972, s. 109);

- współczesność / równoczesność zdarzenia-przyczyny z doznaniem afektu (np. wzruszenie, gniew, smutek) lub uprzedniość (np. wstyd) (Jordanskaja, 
1972, s. 107). I. Nowakowska-Kempna wyróżnia ten parametr dla zdarzeńafektów zaistniałych (Nowakowska-Kempna, 1986, s. 55 i nast.);

- intensywność uczucia-afektu (Nowakowska-Kempna, 1986, ss. 58, 136).

2.1.5. Wskazane wyżej parametry w monografii I. Nowakowskiej-Kempnej stanowią podstawę analizy, która pozwala wykazać różnice semantyczne między poszczególnymi jednostkami (np. ze względu na aktywność / pasywność uczucia lub ze względu na różnice w gradacji nasilenia cechy w szeregach leksemów), a także na selekcjonowanie określonych szerszych kontekstów ze względu na wbudowanie pewnej cechy w strukturę semantyczną jednostki (dotyczy to więc niezestawialności cech). Uwzględniony jest także poziom wyższy od poziomu eksplikacji - poziom semantyczno-syntaktyczny, na którym jednostki charakteryzowane są poprzez liczbę i rodzaj otwieranych pozycji argumentowych. Dla klasy predykatów-postaw emocjonalnych autorka wyróżnia następujące klasy (typ c) nie obejmuje predykatów-afektów):

a) z dwoma argumentami przedmiotowymi i jednym zdaniowym, np. Joanna nienawidzi / nie znosi / nie lubi / nie cierpi kota Filipa za to, że...

b) z jednym argumentem przedmiotowym i jednym zdaniowym, np. Marek nienawidzi / nie lubi / nie znosi / nie cierpi, jak / kiedy Janka gra na fortepianie / gry na fortepianie / grać na fortepianie.

c) z jednym argumentem przedmiotowym, obejmującym klasę przedmiotów jednorodnych, a więc ujmowanych generycznie: Henryk boi się kotów, myszy i pająków. (por. Nowakowska-Kempna, 1986, s. 120).

2.2. Omówione wyżej opracowania stanowią istotny wkład do badań nad analizowanymi w tym tekście klasami, ale skupiają się głównie na cechach poziomu semantycznego, choć w modelu I. Nowakowskiej-Kempnej poziom syntaktyczny również jest zarysowany w powiązaniu z problematyką strukturalizacji tematyczno-rematycznej (por. też niżej, 2.2.2.3.1.).

2.2.1. Ustalanie interpretacji struktur semantycznych poprzez eksplikacje wyczerpujące ogół komponentów semantycznych w nich występujących i pozwalające na dyferencjację jednostek (wskazanie cech różniących każdą z nich od pozostałych) jest zadaniem niezmiernie trudnym, zwłaszcza w wypadku opisu dużych zbiorów. W specyficznych konglomeratach cech semantycznych każdej z badanych jednostek leksykalnych można wyróżnić takie, które wyrażane są wyłącznie poprzez temat czasownika, oraz takie, które sygnalizują pewne treści na poziomie struktur zdaniowych w postaci elementów formalnych. W badaniu, które obejmuje dość liczne klasy czasowników - ok. 500 czasowników 
(a taki zakres analizy jest przyjęty w realizowanym projekcie - por. wyżej, odsyłacz 1) - najważniejsze są podstawowe, obligatoryjne dla danego zbioru cechy struktur semantycznych. Wskazane wyżej, istotne wyniki badań cech semantycznych obu klas niewątpliwie pomagają w ustaleniu takich cech, dając pogłębioną analizę odniesioną do głębszego poziomu, który teoretycznie może w pewien sposób ujawniać się w strukturach zdaniowych.

2.2.1.1. Przyjmuje się więc, że granicą klasy predykatów mentalnych (zarówno prostych, jak i złożonych) jest predykat wiedzy. Stanowi on jądro innych, rozbudowanych semantycznie struktur czasowników tej klasy. Podstawowe podklasy tego zbioru tworzą predykaty stanowe oraz predykaty odnoszące się do operacji, które prowadzą do tego, że obiekt $x$ zmienia swój stan wiedzy (powstaje nowy jej stan), a więc operacje te pozwalają na formułowanie nowych sądów - do takich predykatów należy np. czasownik myśleć ${ }_{2}$ jak / dokąd I dlaczego V... w opozycji do myślé́ ${ }_{1}, \dot{z} e$ V..., który tworzy zdania zawierające w obrębie $q$ sąd (lub więcej niż jeden argument propozycjonalny w wypadku bardziej złożonych operacji). Obligatoryjną pozycją otwieraną przez predykaty mentalne jest argument przedmiotowy (z reguły o cechach [+Hum] / [+Anim]), odnoszący się do obiektu, który jest w stanie mentalnym lub przeprowadza operację mentalną (nośnik stanu / operacji mentalnej - x).

Dla klasy predykatów emocji ustala się, że podstawową, prostą semantycznie jednostką o funkcji predykatu i trzonem ich eksplikacji jest czasownik pol. czuć oraz jego argumenty: argument przedmiotowy $x$, odnoszący się do jednostki, która jest w stanie emocjonalnym (nośnik stanu), również o cechach ([+Hum] / [+Anim]) oraz argument propozycjonalny $q$. Jak już wskazano wyżej, argument ten w głębokiej strukturze semantycznej ma funkcję przyczyny / źródła stanu $x$-a.

2.2.2. Charakter omówionych wyżej prac i wnioski z nich wypływające skłaniają do analiz przeprowadzanych $\mathrm{w}$ granicach cech przejawiających się formalnie w strukturach zdaniowych (a nie jedynie w tematach tych leksemów). Granice te wyznaczają semantyczne kategorie zdaniowe, a więc kategoria modalności, szeroko pojętej temporalności (tu: kategorie aspektualne oraz kategorie czasu sensu stricte), a przede wszystkim składnik propozycjonalny semantycznej struktury zdaniowej (struktura predykatowo-argumentowa) por. też model opisu w: Maliszewska (2001).

2.2.2.1. Kategoria modalności odnosi się do stanu mentalnego aktualnego nadawcy, a więc nie należy do tej analizy jako kategoria aktualizująca, natomiast istotne jest w całościowym opisie wyłonienie czasowników, które implikują hipotetyczność treści wyrażonej w ramach argumentu propozycjonalnego 
(np. jest to implikowanie niepełnej wiedzy $x$ - $a$ o stanie rzeczy, por. watpić, przypuszczać itp.). Ta cecha semantyczna może rzutować na potencjalną / obligatoryjną postać wykładników więzi ze zdaniową realizacją argumentu propozycjonalnego lub narzucać formy czasownika realizującego predykat w jego ramach, np. Wątpię w to, aby Jerzy to zrobił. obok Wątpię $w$ to, że Jerzy to zrobił. Do tych zjawisk należy modyfikacja jednostek poprzez negację, wprowadzającą / uwypuklającą zastrzeżenie prawdziwościowe w obrębie argumentu q, por. np. Nie stwierdzam, aby Jerzy to zrobił. I Nie myślę, abyś dobrze to załatwił. / Nie sadzę, abyś miał rację. itp.

2.2.2.2. Do opisu cech związanych $z$ kategorią temporalności należą treści odnoszące się do (a) temporalności wewnętrznej (aspektu semantycznego) oraz (b) temporalności właściwej (odniesionej do osi czasu). W ramach problemów należących do (a) ważne jest wyodrębnienie tych przypadków, kiedy treści aspektualne, realizowane przez prefiksy, narzucają pewne cechy formalne strukturze zdaniowej ${ }^{3}$. Do tych zjawisk należy na przykład funkcja prefiksu, który implikuje ograniczenia odcinka czasu trwania relacji perduratywnej (por. Przedumaliśmy cała noc, jak rozwiązać tę sytuację:; por. też: Korytkowska [2017]). Innym przykładem może być obligatoryjność wykładnika liczby mnogiej przy realizacji argumentu $q$, kiedy główny predykat odnosi się do wiązki funkcji (por też niżej 3.1.).

Do tej problematyki należy także wspomniana wyżej kwestia wyodrębniania przez I. Nowakowską-Kempną klasy afektów oraz postaw emocjonalnych, zwłaszcza że autorka łączy te ostatnie $\mathrm{z}$ cechą formalną (obligatoryjna fraza pluralna w wypadkach nominalizacji, por. Lubię podróże.) - por. NowakowskaKempna (1986); por. też 2.1.3. Z punktu widzenia kategorii aspektualnych problem jest bardzo złożony. Tak np. S. Karolak reprezentantów obu wyróżnionych przez I. Nowakowską-Kempną grup lokuje w ramach tematów ciągłych, stanowiących stany nieomnitemporalne, „raczej długotrwałe, ale także stany krótkotrwałe, niewykluczające lokalizacji temporalnej”, wśród których wymienia np. bać się, brzydzić się, cierpieć, kochać, lekceważyć, lubić, nienawidzić, tęsknić (por. [Karolak, 2008, ss. 70-85]), a więc jednostki zaliczane przez I. Nowakowską-Kempną zarówno do afektów, jak i do postaw emocjonalnych. Obraz komplikuje też

${ }^{3}$ Część tych zjawisk różnicuje języki, co uwidocznia się w analizie konfrontatywnej, a jest to uwarunkowane istnieniem lub brakiem gramatykalizacji pewnych treści w poszczególnych językach oraz od zakresów tej gramatykalizacji (od dystrybucji jej wykładników); por też: Mazurkiewicz-Sułkowska (2008). 
fakt, że istnieje możliwość użycia bardzo wielu jednostek odnoszących się do afektów (w klasyfikacji I. Nowakowskiej-Kempnej) w funkcji omnitemporalnej w strukturach analogicznych do tych, które mają charakteryzować stany emocjonalne. Problematyka ta wiąże się także z konfiguracją habitualną, która jest przez S. Karolaka określana jako niemająca dyskretnych wykładników. Można więc mówić o potencjalnych interpretacjach w ramach lektury ciągłej lub habitualnej zdania, por. Karolak (2008, s. 177). Tylko systematyczna analiza całego zbioru czasowników mentalnych pod względem obligatoryjności więzi ze zdaniem intensjonalnym $(q)$ w postaci jak / gdy / kiedy oraz obligatoryjności występowania postaci pluralnej frazy w wypadku nominalizacji i szersze obserwacje użycia jednostek w zdaniach o znaczeniu nieaktualnym mogą przynieść bardziej szczegółowe ustalenia ${ }^{4}$.

Analiza semantycznej kategorii temporalności sensu stricte może obejmować jedynie problem nakładania przez czasownik ograniczeń temporalnych na predykat w ramach argumentu / argumentów propozycjonalnych. W obu zbiorach zjawisko to zaznacza się w sposób nikły (było też dostrzeżone w omawianych wyżej pracach).

2.2.2.3. W ramach analizy składnika propozycjonalnego ujęte są dopuszczalne dla poszczególnych czasowników typy struktur zdaniowych i ich interpretacja, na którą składa się ustalenie relacji między dopuszczalnymi strukturami i stopniem kondensacji występującej w poszczególnych typach struktur w wyrażaniu treści argumentów propozycjonalnych. Tak więc wyróżniona zostaje struktura podstawowa, pełna semantycznie, w najszerszym zakresie realizująca cechy danego predykatu (jednostki leksykalnej), która zawiera w przeważającej liczbie wypadków zdanie intensjonalne jako realizacje pozycji q. W strukturach pochodnych od struktury podstawowej treść q jest w różnym stopniu niepełna semantycznie w zakresie realizacji otwieranych pozycji oraz ich treści i bywa zredukowana nawet do pozycji jednego $\mathrm{z}$ argumentów z $\mathrm{q}$ (np. do frazy realizującej jeden $\mathrm{z}$ argumentów przedmiotowych). Pozwala to na interpretację zbiorów dopuszczalnych przez daną jednostkę struktur zdaniowych jako zbioru uporządkowanego hierarchicznie. To podejście oznacza, że we wszystkich tych strukturach występuje semantycznie tożsama jednostka leksykalna w funkcji predykatu - są to na przykład struktury z realizacją zdaniową argumentu propozycjonalnego wobec struktury zawierającej frazę

\footnotetext{
4 Ten aspekt badania jest uwzględniony w realizowanym projekcie.
} 
nominalną w funkcji nominalizacji tego zdania. Takie podejście pozwala też ustalić granice funkcjonowania danej jednostki jako takiej, która ma to samo znaczenie (jak wskazano wyżej, M. Danielewiczowa rozróżnia jednostki w zależności od tego, czy otwierają one pozycję dla frazy nominalnej, czy też dla zdania [Danielewiczowa, 2002, ss. 29-31]). Warto tu podkreślić, że realizowane w projekcie podejście różni się także od tych, które cechuje wiele prac z zakresu leksykografii ${ }^{5}$. Praktyka przypisywania czasownikom różnic znaczenia w przypadkach, które można uznać za efekt pewnej operacji zdań $\mathrm{z}$ tą samą jednostką hasłową, jest powszechna i obecna we współczesnych słownikach (nie tylko polskich). W zastosowanym w projekcie modelu uznanie danej struktury za skondensowaną wynika z możliwości jej interpretacji przez strukturę wyjściową, zawierającą zrealizowane pozycje argumentowe.

Dla analizy składnika propozycjonalnego istotnym zagadnieniem jest także problem lokalizacji argumentów w strukturach zdaniowych, a więc kategoria diatezy, w tym analiza tendencji i mechanizmów występujących w badanych językach.

2.2.2.3.1. Przekształcenia podstawowej struktury zdaniowej są efektem pewnych procesów - $\mathrm{z}$ jednej strony umożliwiają one pominięcie pewnych

${ }^{5}$ Syntetyzowanie faktów płaszczyzny syntaktycznej dla danej jednostki w ramach hasła stosowane jest też w słownik czasowników polskich opartym na teorii generatywnej - por. Polański (1980-1993). W słownikach jednojęzycznych (popularnych) struktura hasła tworzona jest poprzez wyodrębnianie (i numerowanie) jednostek, które określa się najczęściej jako osobne znaczenia i których relacje (także kolejność ich podawania) nie są ściśle określane. Zwykle deklarowane jest usytuowanie znaczeń pokrewnych blisko siebie i w obrębie haseł mogą się znajdować także zupełnie odrębne znaczenia danej jednostki hasłowej. Jest to praktyka powszechna w słownikach języka polskiego i nie tylko (por. np. PSWP, 1994-2005; ISJP, 2000a; też np. РБE, 1977-2015). W przedmowie do ISJP zawarta jest próba uściślenia tego zagadnienia i deklaruje się, że numery znaczeń są w istocie numerami jednostek leksykalnych, które definiuje się jako przedmiot definicji (por. ISJP, 2000b, s. XI), jednak zasada ta wymagałaby sformułowania ściślejszych kryteriów. Tak np. wyodrębniane jest jako oddzielne znaczenie jednostki hasłowej (z reguły jako znaczenie 1.) użycie czasownika bez wypełnionej pozycji argumentowej (o wartości ogólnej tego „zera”), por. np. myśleć 1.: Kiedy myślimy, to w naszym umyśle powstają jakieś sądy, idee, sądy, pomysły itp. - por. z 2.: Jeśli myślimy o jakiejś osobie, rzeczy, sprawie itp., to jest ona przedmiotem naszych myśli. (por. ISJP, 2000b, s. 908). Zgodnie $\mathrm{z}$ tą praktyką, w obrębie jednego hasła występują pod kolejnymi numerami jednostki, których znaczenia nie mają ze sobą żadnego związku - por. np. hasło nudzić, w którym występują znaczenia odnoszące się do stanu wewnętrznego (np. coś nas nudzi - nudzimy się czymś; nudzimy się - nudzi nam się) oraz np. nudzić o coś 'upominać się' (znaczenie 5) - (por. ISJP, 2000b, s. 1049). 
treści struktury pełnej, z drugiej - uczestniczą w wyborze odpowiedniej dla celu komunikatywnego perspektywy funkcjonalnej wypowiedzenia (i realizacji struktury tematyczno-rematycznej T-R - analizę w tym zakresie zawiera monografia I. Nowakowskiej-Kempnej [Nowakowska-Kempna, 1986]). Dla wyczerpującego opisu struktur pod kątem możliwości realizacji odmianek perspektywy funkcjonalnej istotne są jednak nie tylko cechy syntaktyczne zdania, lecz także szyk członów zdaniowych i lokowanie akcentu zdaniowego na członie rematycznym. Tak więc poszczególne typy struktur syntaktycznych o określonym szyku członów dopuszczają zróżnicowane możliwości kształtowania struktury T-R, bądź ją narzucają, a struktura ta może mieć charakter neutralny lub nacechowany (ekspresywny bądź związany z kontekstem, wiążąc się z wymogami spójności tekstu) - por. Karolak (1984, ss. 30-40). Należy podkreślić, że uwzględnienie wszystkich tych wariantów i uzależnień realizacyjnych struktur T-R przekracza założenia projektu (por. odsyłacz 1), szczegółowe i systematyczne ustalanie inwentarza struktur syntaktycznych dla każdej jednostki leksykalnej może stanowić podstawę do późniejszych badań tego zagadnienia (wymaga ono niejednokrotnie także uwzględnienia uwarunkowań szerszego kontekstu).

Poniżej ukazane zostały przykłady opracowania zgodnie z przyjętym modelem inwentarzy struktur zdaniowych dla czasownika cenić z klasy czasowników mentalnych oraz dla cieszyć się - cieszyć z klasy czasowników emocji.

\section{CENIĆ}

(klasa predykatu: $\mathrm{P}_{(\mathrm{x}, \mathrm{q})}$ )

\begin{tabular}{|c|c|c|}
\hline schemat eksplikacyjny & schemat zdaniowy & przykłady polskie \\
\hline 1. $\mathrm{V} \mathrm{N}_{\mathrm{x}}, \mathrm{V}_{\mathrm{q}} \ldots$ & $\mathrm{V} \mathrm{N}_{\text {nom }}$, Pron Con V... & $\begin{array}{l}\text { Te kraje najbardziej cenia to, że maja } \\
\text { petna niezależność. } \\
\text { Zofia ceni to, że dzieci chętnie do niej } \\
\text { przyjeżdzają. } \\
\text { Koledzy cenili to, że Jurek jest znanym } \\
\text { pisarzem. }\end{array}$ \\
\hline 2. $\mathrm{V} \mathrm{N}_{\mathrm{x}}, \mathrm{NV}_{\mathrm{q}} \ldots$ & $\mathbf{V ~ N}_{\text {nom }}, \mathbf{N}_{\mathrm{acc}} \ldots$ & $\begin{array}{l}\text { Dyrektor ceni zdobywanie nowych kwa- } \\
\text { lifikacji. } \\
\text { Polacy cenia wolność. } \\
\text { Cenimy twoje doświadczenie. } \\
\text { Krytycy ceniq dokonania tego twórcy. }\end{array}$ \\
\hline
\end{tabular}




\begin{tabular}{|c|c|c|}
\hline schemat eksplikacyjny & schemat zdaniowy & przykłady polskie \\
\hline 3. $\mathrm{VN}_{\mathrm{x}}, \mathrm{N}_{\mathrm{aq}} \mathrm{V}_{\mathrm{q}} \ldots$ & $\begin{array}{l}\mathrm{V} \mathrm{N}_{\text {nom }}, \text { Prep } \mathrm{N}_{\text {loc }} \text { Pron Con } \\
\mathrm{V} \ldots \\
/ \\
\text { V } \mathrm{N}_{\text {nom }}, \mathrm{N}_{\mathrm{acc}} \text { Prep Pron } \\
\text { Con } \mathrm{V}_{\ldots}\end{array}$ & $\begin{array}{l}\text { Anna ceniła w mężu to, że był z nia szczery. } \\
\text { Kierowcy cenia w tym samochodzie to, że } \\
\text { ma świetne hamulce. } \\
\text { Ala ceni męża za to, że jest z nia szczery. } \\
\text { Kierowcy cenią ten samochód za to, że ma } \\
\text { świetne hamulce. }\end{array}$ \\
\hline 4. $\mathrm{VN}_{\mathrm{x}}, \mathrm{N}_{\mathrm{aq}} \mathrm{NV}_{\mathrm{aq}} \ldots \emptyset_{\mathrm{Vq}}$ & $\begin{array}{l}\text { V } N_{\text {nom }}, \operatorname{Prep} \mathrm{N}_{\text {loc }} \mathrm{N}_{\text {acc }} \cdots \\
/ \\
\mathrm{V} \mathrm{N}_{\text {nom }}, \mathrm{N}_{\text {acc }} \operatorname{Prep} \mathrm{N}_{\mathrm{acc}} \cdots\end{array}$ & $\begin{array}{l}\text { Koledzy cenili w Jurku jego lojalność. } \\
\text { Ciotka ceniła w swoim synu pracowitość. } \\
\text { Koledzy cenili Jurka za (jego) lojalność. } \\
\text { Ciotka ceniła swojego syna za jego ostatnie } \\
\text { osiagnięcie. }\end{array}$ \\
\hline 5. $\mathrm{VN}_{\mathrm{x}}, \mathrm{N}_{\mathrm{aq}} \emptyset_{\mathrm{q}}$ & $\mathrm{VN}_{\text {nom }}, \mathrm{N}_{\text {acc }}$ & $\begin{array}{l}\text { Tacy mężczyźni cenią kobietę niezależną / } \\
\text { kobiety niezależne. } \\
\text { Francuzi cenią polską wódkę. }\end{array}$ \\
\hline 6. $\mathrm{VN}_{\mathrm{x}}, \mathrm{N}_{\mathrm{aq}} \mathrm{N}_{\mathrm{Pq}} \emptyset_{\mathrm{Vq}}$ & $\mathbf{V ~ N}_{\text {nom, }} \mathbf{N}_{\text {acc }}$ Prep $\mathbf{N}_{\text {acc }}$ & Koledzy cenili Jurka jako pisarza. \\
\hline $\begin{array}{l}\text { 7. } \mathrm{V} \mathrm{N}_{\mathrm{x}}, \mathrm{NV}_{\mathrm{aq}} \ldots \mathrm{NV}_{\mathrm{Pq}} \ldots \\
\emptyset_{\mathrm{Vq}}\end{array}$ & $\mathrm{VN}_{\text {nom }}, \mathrm{N}_{\mathrm{acc}} \ldots$ Prep $\mathrm{N}_{\mathrm{acc}} \ldots$ & $\begin{array}{l}\text { Cenimy ich poświęcenie jako przejaw soli- } \\
\text { darności. }\end{array}$ \\
\hline $\begin{array}{l}\text { 8. } \mathrm{V} \mathrm{N}_{\mathrm{x}}, \mathrm{NV}_{\mathrm{aq}} \ldots \operatorname{Adj}_{\mathrm{Pq}} \ldots \\
\emptyset_{\mathrm{Vq}}\end{array}$ & $\mathrm{VN}_{\text {nom }}, \mathrm{N}_{\mathrm{acc}} \ldots$, Prep Adjacc & Cenimy ich poświęcenie jako nadzwyczajne. \\
\hline 9. $\mathrm{VN}_{\mathrm{x}}$, aq pl rec $\emptyset_{\mathrm{q}}$ & $\mathrm{V}_{\text {się }} \mathrm{N}_{\text {nom pl (wzajemnie) }}$ & Koledzy [wzajemnie] się cenili. \\
\hline
\end{tabular}

\section{CIESZYĆ SIE}

(klasa predykatów: $\mathrm{P}_{(\mathrm{x}, \mathrm{q})}$ )

\begin{tabular}{|c|c|c|}
\hline schemat eksplikacyjny & schemat zdaniowy & przykłady polskie \\
\hline 1. $\mathrm{V} \mathrm{N}_{\mathrm{x}}, \mathrm{V}_{\mathrm{q}} \ldots$ & $\begin{array}{l}\text { V } \mathrm{N}_{\text {nom }} \text {, (Prep) (Pron) } \\
\text { Con V ... } \\
/ \\
\mathrm{V} \mathrm{N}_{\text {nom }}, \text { Prep Pron Con } \mathrm{V}\end{array}$ & $\begin{array}{l}\text { Bogdan cieszył się (tym / z tego), że może } \\
\text { zapukać do tych drzwi (/ ponieważ / } \\
\text { z powodu tego, że ...). } \\
\text { Maria cieszyła się, kiedy / gdy / jak Jacek } \\
\text { był wesoły. } \\
\text { / } \\
\text { Chłopiec cieszył się na to, że dostanie } \\
\text { uprawnienia sternika. * }\end{array}$ \\
\hline 2. $\mathrm{V} \mathrm{N}_{\mathrm{x}}, \mathrm{NV}_{\mathrm{q}} \ldots$ & $\begin{array}{l}\mathbf{N}_{\text {nom }}, \mathbf{N}_{\text {instr }} / \text { Prep } N_{\text {gen }} \ldots \\
N_{\text {nom }}, \text { Prep } N_{\text {acc }} \ldots\end{array}$ & $\begin{array}{l}\text { Cieszyliśmy się tymi koncertami. } \\
\text { Krakowianie cieszyli się tym współza- } \\
\text { wodnictwem budowniczych kościoła. } \\
\text { Pies cieszył się z jego powrotu / z powodu } \\
\text { jego powrotu. } \\
\text { Cieszyliśmy się z tych wspólnych zabaw. } \\
\text { Hanka cieszyła się na długa pogawędkę.* }\end{array}$ \\
\hline
\end{tabular}




\begin{tabular}{|c|c|c|}
\hline schemat eksplikacyjny & schemat zdaniowy & przykłady polskie \\
\hline 3. $\mathrm{VN}_{\mathrm{x}}, \mathrm{N}_{\mathrm{aq}} \emptyset_{\mathrm{q}}$ & $\begin{array}{l}\text { V N }_{\text {nom }}, \mathbf{N}_{\text {instr }} / \text { PrepN }_{\text {gen }} \\
/ \\
V_{\text {nom }}, \text { Prep } N_{\text {acc }}\end{array}$ & $\begin{array}{l}\text { Borowski cieszył się dziełami sztuki. } \\
\text { Ta piękna kobieta cieszyła się [juz]] } \\
\text { swoim synkiem. } \\
\text { Gawlikowa cieszyła się puszka praw- } \\
\text { dziwej herbaty. } \\
\text { Moja żona cieszyła sięz } \\
\text { samochodu / z powodu samochodu. } \\
\text { Wiesiek cieszył się na dziecko. }\end{array}$ \\
\hline 4. $\mathrm{V} \mathrm{N}_{\mathrm{x}}, \emptyset_{\mathrm{q}}$ & $\mathrm{V} \mathrm{N}_{\text {nom }}$ & $\begin{array}{l}\text { Dzieci cieszyły się [i śpiewały]. } \\
\text { [W takich chwilach] ludzie się cieszą. }\end{array}$ \\
\hline
\end{tabular}

\section{UWAGA:}

* Wykładnik więzi na (to) występuje w zdaniach $q$ (lub jego nominalizacjach) odniesionych do przyszłości względem predykatu zdania głównego.

\section{CIESZYĆ}

(klasa predykatów: $\mathrm{P}_{(\mathrm{x}, \mathrm{q})}$ )

\begin{tabular}{|c|c|c|}
\hline schemat eksplikacyjny & schemat zdaniowy & przykłady polskie \\
\hline 1. $\mathrm{V} \mathrm{V}_{\mathrm{q}} \ldots, \mathrm{N}_{\mathrm{x}}$ & V (Pron) Con V ... & $\begin{array}{l}\text { Cieszyło mnie to, że chory był coraz silniejszy. } \\
\text { Cieszyło ją to, że wyjedzie na długie wakacje. } \\
\text { Cieszyło mnie, że Jacek był oddany i lojalny. } \\
\text { Ankę cieszy jak / kiedy / gdy Jurek przynosi } \\
\text { jej kwiaty. }\end{array}$ \\
\hline 2. $\mathrm{VNV}_{\mathrm{q}} \ldots, \mathrm{N}_{\mathrm{x}}$ & $\mathrm{V} \mathrm{N}_{\text {nom }} \ldots, \mathrm{N}_{\mathrm{acc}}$ & $\begin{array}{l}\text { Okazywana życzliwośćcieszyła przyjezdnych. } \\
\text { Studentów cieszyło kreowanie czegoś nowego. } \\
\text { Wiesława cieszy zaradność opiekunki. } \\
\text { Ludzi ciesza wspólne osiagnięcia. }\end{array}$ \\
\hline 3. $\mathrm{V} \mathrm{N} \mathrm{N}_{\mathrm{aq}} \emptyset_{\mathrm{q}}, \mathrm{N}_{\mathrm{x}}$ & V $\mathbf{N}_{\text {nom }}, \mathbf{N}_{\text {acc }}$ & $\begin{array}{l}\text { Ten uczeń nas cieszy. } \\
\text { Dziecko cieszyło Martę [każdego dnia]. }\end{array}$ \\
\hline 4. $\mathrm{V} \mathrm{N}_{\text {nom }} \mathrm{V} \ldots, \mathrm{N}_{\mathrm{acc}}$ & $\mathbf{V} \mathbf{N}_{\text {nom }} \mathbf{V} \ldots, \mathbf{N}_{\text {acc }}$ & $\begin{array}{l}\text { Dziecko cieszy mnie, jak / kiedy / gdy wygląda } \\
\text { na szczęśliwe. }\end{array}$ \\
\hline 5. $V N_{\mathrm{aq}} \operatorname{Adj}_{\mathrm{Pq}} \emptyset_{\mathrm{Vq}}, \mathrm{N}_{\mathrm{x}}$ & $\mathrm{V} \mathrm{N}_{\text {nom }}$ Prep Adj $\mathrm{Anom}_{\text {nocc }}, \mathrm{N}_{\mathrm{a}}$ & Ten uczeń nas cieszy jako wybitnie zdolny. \\
\hline 6. $\mathrm{V} \mathrm{N}_{\mathrm{aq}} \mathrm{NV}_{\mathrm{q}} \ldots, \mathrm{N}_{\mathrm{x}}$ & $\mathrm{V} \mathrm{N}_{\text {nom }} \mathrm{N}_{\text {instr }} \ldots, \mathrm{N}_{\mathrm{acc}}$ & Córka nas cieszy swoimi osiągnięciami. \\
\hline 7. $\mathrm{V} \mathbf{V}_{\mathrm{q}} \ldots \mathrm{N}_{\mathrm{aq}}, \mathrm{N}_{\mathrm{x}}$ & $\begin{array}{l}\text { V Pron Con V... Prep } \\
\mathrm{N}_{\text {loc }}, \mathrm{N}_{\mathrm{acc}}\end{array}$ & $\begin{array}{l}\text { Annę cieszyło w synu to, że stat się odpo- } \\
\text { wiedzialny. }\end{array}$ \\
\hline 8. $\mathrm{VNV}_{\mathrm{q}} \ldots \mathrm{N}_{\mathrm{aq}}, \mathrm{N}_{\mathrm{x}}$ & $\begin{array}{l}\mathbf{V} \mathbf{N}_{\text {nom }} \ldots \text { Prep } \mathbf{N}_{\text {loc }} / \\
\text { Prep } \mathbf{N}_{\text {gen }}\end{array}$ & $\begin{array}{l}\text { Lekarza cieszyła w chorym / u chorego coraz } \\
\text { większa wola życia. }\end{array}$ \\
\hline
\end{tabular}


Ukazane w tabelach przykłady ilustrują procesy, jakim mogą podlegać struktury wyjściowe (por. strukturę nr $1 \mathrm{w}$ tabelach). Obejmują one najbardziej rozpowszechnione struktury zawierające nominalizacje pozycji $q$ (por. strukturę $\mathrm{nr} 2 \mathrm{w}$ tabelach), ale także struktury, w których jeden $\mathrm{z}$ argumentów $\mathrm{z} q$ jest „wyniesiony”, natomiast reszta treści $q$ realizowana jest w różnym stopniu (por. struktury nr 3, 4, $6 \mathrm{w}$ tabeli CENIĆ, nr 3, 6, 8; w tabeli CIESZYĆ) - treść ta może mieć postać zdaniową lub różnych jej przekształceń, a fraza $\mathrm{N}_{\mathrm{aq}}$ może być jedynym elementem realizującym pozycję $q$ (por. strukturę $\mathrm{nr} 5 \mathrm{w}$ tabeli CENIĆ oraz $\mathrm{nr} 3 \mathrm{w}$ tabelach CIESZYĆ SIĘ i CIESZYĆ). Szczególny charakter mają struktury motywowane postacią predykatu $\mathrm{z} q$ : są one realizowane w wypadkach, kiedy $q$ ma charakter predykatu analitycznego, a pozycja ta ma reprezentację $\mathrm{w}$ postaci jednego $\mathrm{z}$ argumentów $\left(\mathrm{N}_{\mathrm{aq}}\right)$ oraz elementu o funkcji orzecznika w zdaniowej postaci $q$ (por. struktury nr 6, 7, $8 \mathrm{w}$ tabeli CENIĆ oraz nr $6 \mathrm{w}$ tabeli CIESZYĆ SIĘ). W ten sposób „wyniesieniu” podlegają orzeczniki realizowane na przykład przez przymiotniki i rzeczowniki, por. Cieszy nas to, że ten uczeń jest wybitnie zdolny. $\rightarrow$ Ten uczeń nas cieszy jako wybitnie zdolny ${ }^{6}$.

3. Zilustrowane dla trzech jednostek struktury nie wyczerpują całych zbiorów typów struktur, jakie dokumentuje materiał obejmujący całą klasę, można też stwierdzić, że oba zbiory (dla czasowników mentalnych oraz czasowników emocji) nie są takie same. Analiza różnic i podobieństw w tym zakresie wymaga pogłębionego przebadania zjawisk w obrębie podstawowych kategorii zdaniowych (zgodnie z przyjętymi kryteriami) i dlatego poniżej zasygnalizowane zostały jedynie wybrane cechy różnicujące.

3.1. Zjawiska w ramach kategorii aspektu semantycznego.

Zbiór czasowników mentalnych zawiera jednostki sygnalizujące funkcję o charakterze złożonym, a więc wiązkę / zbiór stanów (por. Karolak, 2008, s. 191). Istnienie podklasy czasowników mentalnych o charakterze dystrybutywnym dotyczy oczywiście podzbioru o charakterze operacji na wiedzy. Część struktur zdaniowych z takimi czasownikami cechuje się występowaniem fraz (efektów nominalizacji $\mathrm{NV}_{\mathrm{q}}$ lub „wyniesionych" fraz $\mathrm{N}_{\mathrm{aq}}$ ) z obligatoryjną cechą pluralis - $\mathrm{w}$ języku polskim są to na przykład czasowniki zawierające prefiks dystrybutywny po-, por. poprzypominać sobie $\left(\mathrm{P}_{(\mathrm{x}, \mathrm{q}}\right)$, pooceniać:

${ }^{6}$ O typie struktur z jako w kontekście problemu granicy dla pozycji intensjonalnych por. też: Korytkowska (2014; w druku); o funkcjach jako por. Rogowska (1981). 
$\mathrm{V} \mathrm{N}_{\mathrm{x}}, \mathrm{NV}_{\mathbf{q} \mathbf{p l}} \ldots \rightarrow \mathrm{V} \mathrm{N}_{\text {nom }}, \mathbf{N}_{\mathrm{acc} \mathbf{p l}} \ldots$

Poprzypominat sobie swoje podróże po Afryce.

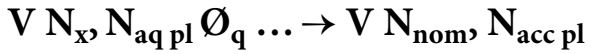

[Na spotkaniu naszej klasy] poprzypominaliśmy sobie kolegów.

$\mathbf{V ~ N}_{\mathbf{x}}, \mathbf{N V}_{\mathbf{q} \mathbf{p l}} \ldots \rightarrow \mathbf{V} \mathbf{N}_{\text {nom }}, \mathbf{N}_{\text {acc pl }} \ldots$

[Wczoraj] trenerzy pooceniali postępy zawodników.

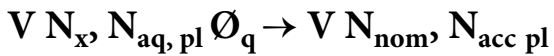

Hubert pooceniał kandydatki na modelki.

Czasowniki emocji nie poświadczają takiego typu, co jest uzasadnione ze względu na stanowy charakter tych predykatów. Oczywiście pewne typy aspektualne (w tym także amalgamaty aspektualne ${ }^{7}$ ), jak na przykład sygnalizujące początek lub koniec stanu / operacji, a więc np. inchoatywne z suf. $z a$ - (por. np. zainteresować się, zaniepokoić się) lub np. limitatywne, implikujące rozciągłość w czasie z suf. prze- (przemarzyć / przecierpieć cały miesiąc) itp., poświadczone są w obu zbiorach. Por. też Karolak (2008, s. 127 i nast., 161 i nast.) ${ }^{8}$.

3.2. Zjawiska w ramach składnika propozycjonalnego.

3.2.1. W zdaniach $\mathrm{z}$ czasownikami emocji ujawnia się istotna cecha ich struktury semantycznej, to znaczy występowanie przyczyny powstania stanu emocjonalnego. $Z$ reguły ta treść jest wyrażana w obrębie argumentu propozycjonalnego (por. wyżej) (Jordanskaja, 1972, s. 107; Nowakowska-Kempna, 1986, s. 46). Tego rodzaju strukturalizacja treści nie blokuje możliwości występowania w rozwiniętej strukturze zdaniowej zdania przyczynowego ekstensjonalnego, por. np. Anna cieszy się, że jutro wyjedzie na urlop, ponieważ jest bardzo zmęczona. Z drugiej strony istnieją zdania typu Anna cieszy się, ponieważ jutro wyjedzie na urlop. Por. też: Zofia denerwuje się spóźnianiem się Piotra. - Zofia denerwuje się z powodu spóźniania się Piotra. Precyzując relację między zdaniami tego typu (z że i ponieważ / bo), I. Nowakowska-Kempna odwołuje się do koncepcji S. Karolaka, który wyróżnia tzw. przyczynę sprawczą (wyrażaną $\mathrm{w}$ zdaniu intensjonalnym, a więc wbudowaną w strukturę predykatu) oraz

7 Por. klasyfikację typów aspektów, w tym aspektów złożonych, w Karolak (2008).

8 Zakresy tych zjawisk mogą różnić języki, co wiąże się z odmiennie przebiegającą gramatykalizacją poszczególnych kategorii semantycznych, stąd problematyka ta jest interesująca konfrontatywnie. 
przyczynę poznawczą (wyrażaną poprzez zdanie w pozycji ekstensjonalnej). Struktury typu Zofia denerwuje się, ponieważ Piotr się spóźnia. interpretowane są jako szczególne, kiedy w przypadku braku wypełnienia pozycji intensjonalnej zdanie ekstensjonalne (przyczyna poznawcza) zajmuje pozycję argumentową (por. Karolak, 1979; Nowakowska-Kempna, 1986, s. 166; por. też Korytkowska, w druku). Można jednak stwierdzić, że mutatis mutandis analogiczna interpretacja dotyczy też struktur - efektów kondensacji, np. Zofia denerwuje się z powodu spóźniania się Piotra. / Dziecko cieszy się z nowej zabawki / z powodu nowej zabawki. itp. Nieostrość granicy między pozycją intensjonalną i ekstensjonalną w klasie czasowników emocji uwidacznia się także w pozycji zdań podrzędnych wprowadzanych przez jak / kiedy / gdy typu Cieszę się, jak wracasz wcześniej do domu. - Cieszę się z twoich wcześniejszych powrotów do domu. (i nie można im przypisać interpretacji w postaci zdania z niewypełnioną / nieokreśloną pozycją q, por. ${ }^{*}$ Cieszę się [czymś / z czegoś], jak wracasz wcześniej do domu.). Można przypuszczać, że w specyficzny sposób uogólnione okoliczności pewnego stanu są bliskie sformułowaniu przyczyny tego stanu. Omawianego typu struktur brak w klasie czasowników mentalnych, a dopuszczalne zdania typu Myślę, jak / kiedy wrócisz do domu. podlegają nominalizacji innego typu, por. Myślę, jak / kiedy wrócisz do domu. - Myślę, w jaki sposób / o jakiej porze wrócisz do domu. (por. też Korytkowska, 2017).

3.2.2. Czasowniki mentalne charakteryzuje rozbudowany zbiór struktur przekształconych (skondensowanych) także dlatego, że część z nich to predykaty trzymiejscowe, odnoszące się do różnych operacji myślowych, w tym operacji logicznych, jak np. alternatywa, koniunkcja czy konkluzja - pociąga to za sobą często bardziej rozbudowane struktury zdaniowe i wymaga uwzględnienia wielu wariantów na przykład w zakresie dopuszczalności / braku dopuszczalności niewyrażenia części pozycji argumentowych. Por. przykładowe struktury $\mathrm{z}$ czasownikiem kojarzyć się $\left(\mathrm{P}_{(\mathrm{x}, \mathrm{q}, \mathrm{r})}\right)$ :

$\mathrm{V} \mathrm{V}_{\mathbf{q}} \ldots, \mathrm{N}_{\mathrm{x}}, \mathrm{NV}_{\mathbf{r}} \ldots \rightarrow \mathrm{V}$ Pron V ..., $\mathbf{N}_{\text {dat }}$, Prep $\mathrm{N}_{\mathrm{instr}} \ldots$

To, jak postępujesz, kojarzy mi się z brakiem wychowania.

$\mathrm{V} \mathrm{NV}_{\mathbf{q}} \ldots, \mathrm{N}_{\mathbf{x}}, \mathrm{V}_{\mathbf{r}} \ldots \rightarrow \mathrm{V} \mathrm{N}_{\text {nom }}, \mathrm{N}_{\text {dat }}$, Prep Pron Con V ...

Sposób postępowania Tomka kojarzy mi się z tym, jak się zachowują ludzie niewychowani.

$\mathrm{V} \mathrm{NV}_{\mathrm{q}} \ldots, \mathrm{N}_{\mathrm{x}}, \mathrm{NV}_{\mathrm{r}} \ldots \rightarrow \mathrm{V} \mathrm{N}_{\text {nom }} \ldots, \mathrm{N}_{\mathrm{dat}}$, Prep $\mathrm{N}_{\text {instr }} \ldots$

Odpoczynek kojarzył się większości wczasowiczów z wylegiwaniem się na słońcu. 
$\mathrm{V} \mathrm{NV}_{\mathbf{q}} \ldots, \mathrm{N}_{\mathrm{x}}, \mathrm{N}_{\mathrm{ar}} \boldsymbol{\emptyset}_{\mathbf{r}} \rightarrow \mathrm{V} \mathrm{N}_{\text {nom }} \ldots, \mathrm{N}_{\text {dat }}$, Prep $\mathrm{N}_{\text {instr }}$

Obecność robactwa $w$ bloku kojarzyła się mieszkańcom $z$ sympatycznym staruszkiem.

$\mathrm{V} \mathrm{V}_{\mathrm{q}} \ldots, \mathrm{N}_{\mathrm{x}}, \mathrm{N}_{\mathrm{ar}} \boldsymbol{\emptyset}_{\mathbf{r}} \rightarrow \mathrm{V}$ Pron V ..., $\mathbf{N}_{\text {dat }}$, Prep $\mathrm{N}_{\mathrm{intr}}$

To / Fakt, że w domu było pełno robactwa, kojarzył(o) się mieszkańcom z sympatycznym staruszkiem.

$\mathrm{V} \mathrm{N}_{\mathrm{aq}} \boldsymbol{\emptyset}_{\mathrm{q}}, \mathbf{N}_{\mathrm{x}}, \mathrm{NV}_{\mathbf{r}} \ldots \rightarrow \mathrm{V} \mathrm{N}_{\text {nom }}, \mathbf{N}_{\mathrm{dat}}$, Prep $\mathbf{N}_{\text {instr }} \ldots$

Jackowi kanarek kojarzy się $z$ wizytami w domu jego stryja.

$\mathbf{V} \mathbf{N}_{\mathrm{aq}} \boldsymbol{\emptyset}_{\mathrm{q}}, \mathbf{N}_{\mathrm{x}}, \mathbf{N}_{\mathrm{ar}} \boldsymbol{\emptyset}_{\mathbf{r}} \rightarrow \mathbf{V ~ \mathbf { N } _ { \text { nom } }}, \mathbf{N}_{\text {dat }}$, Prep $\mathbf{N}_{\text {instr }}$

Emaus zawsze kojarzył się krakowianinom z figurkami Żydów.

Rozbudowane struktury predykatowo-argumentowe mogą też dopuszczać kompresję dwóch pozycji dla argumentów propozycjonalnych, co przejawia się $\mathrm{w}$ postaci jednej pluralnej frazy nominalnej, por. struktury z czasownikiem mylić się $\left(\mathrm{P}_{(\mathrm{x}, \mathrm{q}, \mathrm{r})}\right)$ :

$\mathrm{V} \mathrm{NV}_{\mathbf{q}} \ldots, \mathrm{N}_{\mathrm{x}}, \mathrm{V}_{\mathbf{r}} \ldots \rightarrow \mathrm{V} \mathrm{N}_{\text {nom }} \ldots, \mathbf{N}_{\mathrm{dat}}$, Prep Pron V $\ldots$

Relacja Agaty myliła się Jerzemu z tym, co ustyszał od matki.

$\mathrm{V} \mathrm{NV}_{\mathrm{q}} \ldots, \mathrm{N}_{\mathrm{x}}, \mathrm{NV}_{\mathrm{r}} \ldots \rightarrow \mathrm{V} \mathrm{N}_{\text {nom }} \ldots, \mathrm{N}_{\text {dat }}$, Prep $\mathrm{N}_{\text {instr }} \ldots$

Niepodległość Azerbejdżanu myliła mu się z niczym nieskrępowana swoboda własnych rządów.

$\mathrm{V} \mathrm{N}_{\mathrm{ap}} \emptyset_{\mathrm{q}} \ldots, \mathrm{N}_{\mathrm{x}}, \mathbf{N}_{\mathrm{ar}} \emptyset_{\mathrm{r}} \rightarrow \mathrm{V} \mathrm{N_{ \text {nom } }}, \mathbf{N}_{\mathrm{dat}}$, Prep $\mathbf{N}_{\text {instr }}$

Mongolia myliła mu się z Koreą.

oraz:

$\mathrm{V} \mathrm{N}_{\mathrm{aq}, \text { ar pl }} \emptyset_{\mathrm{q}}, \emptyset_{\mathrm{r}}, \mathrm{N}_{\mathrm{x}} \rightarrow \mathrm{V} \mathrm{N} \mathrm{N}_{\mathrm{pl}}, \mathrm{N}_{\mathrm{dat}}$

Mylity mi się pedały.

$\mathrm{V} \mathrm{NV}_{\mathbf{q}, \mathbf{r} \mathbf{p l}} \ldots \rightarrow \mathrm{V} \mathrm{N}_{\text {nom pl }}, \mathbf{N}_{\text {dat }}$

Mylity mu się role.

Myliła mu się kolejność i okoliczności.

3.2.3. Lokalizacja pozycji argumentowych.

W obu klasach istnieją struktury z odmienną lokalizacją członów zdaniowych, w związku z czym fraza argumentowa $x$ może zajmować pozycję $\mathrm{w}$ podmiocie lub poza podmiotem. Zjawisko to ma jednak zupełnie inny zakres i odmienną realizację w każdej z klas. 
3.2.3.1. W klasie czasowników mentalnych z reguły argument $x$ ([+Anim] [+Hum]) zajmuje pozycję podmiotową. Lokalizacja tego argumentu poza podmiotem jest w języku polskim zjawiskiem rzadkim i może powodować występowanie par czasowników:

$\mathrm{V}-\mathbf{V}_{\text {się }}$

gdzie w zdaniach $\mathrm{z} \mathrm{V} x$ występuje w pozycji podmiotowej, a w $\mathrm{zdaniach} \mathrm{z} \mathrm{V}_{\text {się }}$ w pozycji poza podmiotem, por. np.

a) Stefan [latami] marzył o emigracji do Ameryki i o podbiciu świata.

a') Naserowi marzyło się posiadanie pierwszej na świecie arabskiej broni.

Zdania typu a') potencjalnie tworzone są przez różne jednostki, często okazjonalnie, por. zdanie z czasownikiem uświadamiać (zasłyszane z radia): Uświadomiło mi się, że nie jest to dobre rozwiązanie 9 . Zjawiska te nie są w tej klasie czasowników częste.

3.2.3.2. Oscylowanie pozycji argumentowej $x$ między pozycją podmiotową i pozapodmiotową w zbiorach czasowników otwierających pozycję dla argumentu typu Experiencer jest, jak wiadomo, zjawiskiem bardzo częstym $\mathrm{w}$ językach słowiańskich ${ }^{10}$, w związku z czym pary typu

$$
\mathbf{V}_{\text {się }}-\mathbf{V}
$$

w klasie czasowników emocji, gdzie $\mathrm{V}_{\text {się }}$ tworzy zdania $\mathrm{z} \mathrm{x}$ w pozycji podmiotowej, a $\mathrm{V}$ zdania w pozycji poza podmiotem, są bardzo liczne (nie jest to jednak zjawisko na tyle regularne, żeby można je było uznać za zgramatykalizowane, jak np. struktury pasywne) - np. Jerzy wzruszył się jej odpowiedzią. - Jej odpowiedź wzruszyła Jerzego.; por. też wyżej, przykłady dla czasowników CIESZYĆ SIĘ - CIESZYĆ.

4. Szczegółowe analizy cech poszczególnych jednostek w parafrazach pozwalają wskazać bardzo subtelne nieraz różnice semantyczne między

9 Struktury tego typu mają szerszą dystrybucję - występują także poza klasą czasowników mentalnych. Mogą się charakteryzować nacechowaniem stylistycznym, zwłaszcza w przypadku czasowników agentywnych, odnoszących się do operacji podlegających kontroli, ponieważ dochodzi wówczas do deagentywizacji, np. Tak mi się to powiedziało. (por. częste określenia takich konstrukcji: 'samo się tak zrobiło'). Zjawisko jest interesujące także w perspektywie konfrontatywnej, ponieważ ta idiomatyczna cecha różnicuje języki słowiańskie, por. Korytkowska (1990, 1992); Korytkowska i Mazurkiewicz-Sułkowska (2014); Kiklewicz (w druku).

${ }^{10}$ Por. szerzej o tych zjawiskach w języku polskim i bułgarskim w Korytkowska (1992). 
nimi. Większość tych cech implikowana jest przez morfemy tematyczne i nie przejawia się na poziomie struktur zdaniowych. W artykule wskazuje się, że badanie obejmujące warstwę semantyczno-syntaktyczną poszczególnych klas semantycznych czasowników pozwala uwidocznić fakt, że pewne różnice i podobieństwa między tymi klasami w warstwie semantycznej mogą znajdować odbicie w zakresie cech przejawiających się w warstwie formalnej tworzonych zdań i takie wnioski dotyczą także badań konfrontatywnych. Opracowanie jest też próbą syntetyzującego podejścia do opisu właściwości semantycznych jednostek predykatywnych oraz zjawisk występujących w tworzonych przez nie strukturach.

\section{Wykaz skrótów}

$\mathbf{P}_{(\mathbf{x . q})}-$ predykat $\mathrm{z}$ argumentami

V - czasownik - w pozycji inicjalnej schematów odnosi się do głównego predykatu

$\mathbf{N}_{\mathbf{x}} \quad$ - fraza nominalna w pozycji argumentu $x$

$\mathbf{V}_{\mathbf{q}} \ldots$ - czasownik (wraz z uzupełnieniami) realizujący pozycję $q$

$\mathbf{V I}_{\mathbf{q}}$... - czasownik w formie infinitiwu (wraz z uzupełnieniami) realizujący pozycję $q$

$\mathbf{N V}_{\mathbf{q}}$... - fraza nominalna - efekt nominalizacji pozycji $q$ (wraz z uzupełnieniami)

$\mathbf{N}_{\mathrm{aq}} \quad$ - fraza nominalna realizująca jedną z pozycji $\operatorname{argumentowych~z~} q$

$\mathbf{N}_{\mathbf{P q}}$ - fraza nominalna realizująca orzecznik w podstawowej strukturze zdaniowej

$\mathbf{A d j}_{\mathbf{P q}}$ - adiectivum realizujące orzecznik w podstawowej strukturze zdaniowej

$\emptyset_{\mathbf{q}} \quad$ - brak realizacji $q$ / predykatu z $q$

$\emptyset_{\mathrm{Vq}} \quad$ - brak realizacji copuli predykatora imiennego $\mathrm{z} q$

$\mathbf{N}_{\text {nom - fraza w nominatiwie }}$

$\mathbf{N}_{\text {gen }}$ - fraza z genetiwie

$\mathbf{N}_{\text {acc }}$ - fraza w accusatiwie

$\mathbf{N}_{\text {instr }}$ - fraza w instrumentalu

$\mathbf{N}_{\text {loc }}$ - fraza w locatiwie

Adj $_{\text {nom - adiectivum w nominatiwie }}$

$\mathbf{A d j}_{\text {acc }}$ - adiectivum w accusatiwie

Con - spójnik

Pron - zaimek prosentencjalny ( $t o$ )

rec - funkcja recyprokalna

[...] - elementy nienależące do struktury predykatowo-argumentowej 


\section{Bibliografia cytowanych prac}

Danielewiczowa, M. (2002). Wiedza i niewiedza: Studium polskich czasowników epistemicznych. Warszawa: Uniwersytet Warszawski.

Jordanskaja, L. N. (1972). Próba leksykograficznego opisu znaczeń grupy słów oznaczających uczucia. W: A. Wierzbicka (Red.), Semantyka i słownik (ss. 105-129). Wrocław: Zakład Narodowy im. Ossolińskich. Wydawnictwo PAN.

Karolak, S. (1979). Z problematyki zdań nieosobowych z wyrazami kategorii stanu a kondensacje formalnej struktury wypowiedzenia. W: Реферати од Х заседание на Меѓународната комисија за изучаванје на граматичката структура на словенските литературни јазици. Скопје (ss. 135-150).

Karolak, S. (1984). Składnia wyrażeń predykatywnych. W: Z. Topolińska (Red.), Gramatyka współczesnego języka polskiego: Składnia. Warszawa: PWN.

Karolak, S. (2008). Gramatyka konfrontatywna bułgarsko-polska: T. 8. Semantyczna kategoria aspektu. Warszawa: Slawistyczny Ośrodek Wydawniczy.

Kiklewicz, A. (2015). Синтаксическая информация в лексикографическом описании слова (на примере ментальных глаголов). W: A. Kamalova (Red.), Русская лексикография вчера, сегодня, завтра (ss. 33-57). Olsztyn: CBEW.

Kiklewicz, A. (2017). Walencja rosyjskich czasowników mentalnych w konstrukcjach diatezy afektywnej. Prace Filologiczne, 70, 251-272.

Kiklewicz, A., \& Korytkowska, M. (2012). Экспликатывный синтаксис как информационная база лексикографического описания глаголов (на материале польского и русского языков). Acta Linguistica Petropolitana, 8(3), 279-297.

Kiklewicz, A., \& Korytkowska, M. (2013a). Modelowanie płaszczyzny syntaktycznej segmentacja hasła słownikowego (na przykładzie języków słowiańskich). Biuletyn PTJ, (68), 49-68.

Kiklewicz, A., \& Korytkowska, M. (2013b). O modelu składni semantycznej w perspektywie opisu leksykograficznego czasowników (na materiale języka bułgarskiego i polskiego). W: L. Krumova-Cvetkova et al. (Red.), 70 years Bulgarian academic lexicography (ss. 124-132). Sofia: BAN.

Korytkowska, M. (1990). Z problematyki składni konfrontatywnej, na przykładzie bułgarskich i polskich zdań bezpodmiotowych. Wrocław: Ossolineum.

Korytkowska, M. (1992). Gramatyka konfrontatywna bułgarsko-polska: T. 5. Typy pozycji predykatowo-argumentowych. Warszawa: Slawistyczny Ośrodek Wydawniczy.

Korytkowska, M. (2014). O predykatorach analitycznych w strukturze argumentu propozycjonalnego (na materiale języka bułgarskiego i polskiego). Acta Universitatis Wratislaviensis. Slavica Wratislaviensia, 159, 207-217.

Korytkowska, M. (2017). Intensja czy ekstensja? (O pewnych dylematach przy analizie struktur predykatowo-argumentowych). Prace Filologiczne, 70, 305-316.

Korytkowska, M., \& Kiklewicz, A. (2016). Opis właściwości walencyjnych czasowników na podstawie teorii składni eksplikacyjnej - problemy konfrontatywne i leksykograficzne (na przykładzie języka bułgarskiego, polskiego i rosyjskiego). W: K. Skwarska \& E. Kacz- 
marska (Red.), Výzkum slovesné valence ve slovanských zemích (ss. 291-304). Praha: Slovanský ústav AV ČR.

Korytkowska, M., \& Mazurkiewicz-Sułkowska, J. (2014). O konfrontatywnym badaniu polskich i bułgarskich czasowników mentalnych. Rocznik Slawistyczny, 63, 47-76.

Maliszewska, A. (2001). O problemie kryteriów klasyfikacyjnych predykatorów mentalnych. Rozprawy Komisji Językowej ŁTN, 46, 91-133.

Mazurkiewicz-Sułkowska, J. (2008). Wyrażanie kategorii inchoatywności w językach polskim, bułgarskimi białoruskim. Łódź: Wydawnictwo „Piktor”.

Nowakowska-Kempna, I. (1986). Konstrukcje zdaniowe z leksykalnymi wykładnikami uczuć. Katowice: Uniw. Śląski.

Rogowska, M. (1981). Funkcje gramatyczne słowa jako. Polonica, 7, 161-175.

\section{Słowniki}

Bańko, M. (Red.). (2000a). Inny słownik języka polskiego [ISJP] (2. wyd., T. 1-2). Warszawa: PWN.

Bańko, M. (Red.). (2000b). Inny słownik języka polskiego: T. 1. A-ó [ISJP] (2. wyd., T. 1). Warszawa: PWN.

Polański, K. (Red.). (1980-1993). Słownik syntaktyczno-generatywny czasowników polskich (T. 1-7). Wrocław: Zakład Narodowy im. Ossolińskich.

Zgółkowa, M. (Red.). (1994-2005). Praktyczny słownik współczesnej polszczyzny [PSWP] (T. 1-50). Poznań: Wyd. Kurpisz.

Речник на българския език [РБЕ]. (1977-2015) (Т. 1-15). София: Издателство на БАН “Проф. Марин Дринов".

\section{Bibliography (Transliteration)}

Danielewiczowa, M. (2002). Wiedza i niewiedza: Studium polskich czasowników epistemicznych. Warszawa: Uniwersytet Warszawski.

Jordanskaja, L. N. (1972). Próba leksykograficznego opisu znaczeń grupy słów oznaczających uczucia. In A. Wierzbicka (Ed.), Semantyka i słownik (pp. 105-129). Wrocław: Zakład Narodowy im. Ossolińskich. Wydawnictwo PAN.

Karolak, S. (1979). Z problematyki zdań nieosobowych z wyrazami kategorii stanu a kondensacje formalnej struktury wypowiedzenia. In Referati od X zasedanie na Meǵunarodnata komisija za izučavanje na gramatičkata struktura na slovenskite literaturni jazici. Skopje (pp. 135-150). 
Karolak, S. (1984). Składnia wyrażeń predykatywnych. In Z. Topolińska (Ed.), Gramatyka współczesnego języka polskiego: Składnia. Warszawa: PWN.

Karolak, S. (2008). Gramatyka konfrontatywna bułgarsko-polska: Vol. 8. Semantyczna kategoria aspektu. Warszawa: Slawistyczny Ośrodek Wydawniczy.

Kiklewicz, A. (2015). Sintaksicheskaia informatsiia v leksikograficheskom opisanii slova (na primere mental'nykh glagolov). In A. Kamalova (Ed.), Russkaia leksikografiia vchera, segodnia, zavtra (pp. 33-57). Olsztyn: CBEW.

Kiklewicz, A. (2017). Walencja rosyjskich czasowników mentalnych w konstrukcjach diatezy afektywnej. Prace Filologiczne, 70, 251-272.

Kiklewicz, A., \& Korytkowska, M. (2012). Ėksplikatyvnyı̆ sintaksis kak informatsionnaia baza leksikograficheskogo opisaniia glagolov (na materiale pol'skogo i russkogo iazykov). Acta Linguistica Petropolitana, 8(3), 279-297.

Kiklewicz, A., \& Korytkowska, M. (2013a). Modelowanie płaszczyzny syntaktycznej segmentacja hasła słownikowego (na przykładzie języków słowiańskich). Biuletyn PTJ, (68), 49-68.

Kiklewicz, A., \& Korytkowska, M. (2013b). O modelu składni semantycznej w perspektywie opisu leksykograficznego czasowników (na materiale języka bułgarskiego i polskiego). In L. Krumova-Cvetkova et al. (Eds.), 70 years Bulgarian academic lexicography (pp. 124-132). Sofia: BAN.

Korytkowska, M. (1990). Z problematyki składni konfrontatywnej, na przykładzie bułgarskich i polskich zdań bezpodmiotowych. Wrocław: Ossolineum.

Korytkowska, M. (1992). Gramatyka konfrontatywna bułgarsko-polska: Vol. 5. Typy pozycji predykatowo-argumentowych. Warszawa: Slawistyczny Ośrodek Wydawniczy.

Korytkowska, M. (2014). O predykatorach analitycznych w strukturze argumentu propozycjonalnego (na materiale języka bułgarskiego i polskiego). Acta Universitatis Wratislaviensis. Slavica Wratislaviensia, 159, 207-217.

Korytkowska, M. (2017). Intensja czy ekstensja? (O pewnych dylematach przy analizie struktur predykatowo-argumentowych). Prace Filologiczne, 70, 305-316.

Korytkowska, M., \& Kiklewicz, A. (2016). Opis właściwości walencyjnych czasowników na podstawie teorii składni eksplikacyjnej - problemy konfrontatywne i leksykograficzne (na przykładzie języka bułgarskiego, polskiego i rosyjskiego). In K. Skwarska \& E. Kaczmarska (Eds.), Výzkum slovesné valence ve slovanských zemích (pp. 291-304). Praha: Slovanský ústav AV ČR.

Korytkowska, M., \& Mazurkiewicz-Sułkowska, J. (2014). O konfrontatywnym badaniu polskich i bułgarskich czasowników mentalnych. Rocznik Slawistyczny, 63, 47-76.

Maliszewska, A. (2001). O problemie kryteriów klasyfikacyjnych predykatorów mentalnych. Rozprawy Komisji Językowej ŁTN, 46, 91-133.

Mazurkiewicz-Sułkowska, J. (2008). Wyrażanie kategorii inchoatywności w językach polskim, bułgarskimi białoruskim. Łódź: Wydawnictwo "Piktor."

Nowakowska-Kempna, I. (1986). Konstrukcje zdaniowe z leksykalnymi wykładnikami uczuć. Katowice: Uniw. Śląski.

Rogowska, M. (1981). Funkcje gramatyczne słowa jako. Polonica, 7, 161-175. 


\section{Dictionaries}

Bańko, M. (Ed.). (2000a). Inny słownik języka polskiego [ISJP] (2 ${ }^{\text {nd }}$ ed., Vols. 1-2). Warszawa: PWN. Bańko, M. (Ed.). (2000b). Inny słownik języka polskiego: Vol. 1. A-ó [ISJP] (2nd ed., Vol. 1). Warszawa: PWN.

Polański, K. (Ed.). (1980-1993). Słownik syntaktyczno-generatywny czasowników polskich (Vols. 1-7). Wrocław: Zakład Narodowy im. Ossolińskich.

Rechnik na bŭlgarskiia ezik [RBE]. (1977-2015) (Vols. 1-15). Sofiia: Izdatel'stvo na BAN "Prof. Marin Drinov."

Zgółkowa, M. (Ed.). (1994-2005). Praktyczny słownik współczesnej polszczyzny [PSWP] (Vols. 1-50). Poznań: Wyd. Kurpisz.

\section{Mental and emotional verbs in semantic and syntactic description}

\section{Summary}

The main issue of this article concerns relations between the semantic plane of the sentence, which is presented by means of notions of predicate-argument structure, and the plane of formal realisation of this structure. The existing attitudes to the studied verb classes are presented. Then rules governing the model of description used are specified (the article has been written within an elaborate scientific grant concerning Bulgarian, Polish and Russian). Obligatory semantic features of both classes are pointed out, followed by an elaboration on the scope of analysis of semantic and syntactic phenomena. This scope is determined by basic semantic sentence categories on which comparative, including contrastive, research is based. Drawing on examples of particular units studied, I then discuss the effectiveness of the analysis which enables comparing differences between sets of sentence structures allowable for each class studied. Those differences stem from semantic differences typical of those classes. 


\section{Czasowniki mentalne i czasowniki emocji w opisie semantyczno-syntaktycznym}

\section{Streszczenie}

Tematyka artykułu dotyczy relacji między płaszczyzną semantyczną zdania, ujętą $\mathrm{w}$ terminach struktury predykatowo-argumentowej, a płaszczyzną realizacji formalnej tej struktury. Zarysowane zostały dotychczasowe podejścia do opisu badanych klas czasowników oraz sprecyzowano ustalenia dotyczące zastosowanego w artykule modelu opisu (artykuł powstał w związku z realizacją obszernego grantu dotyczącego języka bułgarskiego, polskiego i rosyjskiego). Wskazano obligatoryjne dla obu klas cechy semantyczne oraz scharakteryzowano zakres analizy zjawisk semantyczno-składniowych. Zakres ten wyznaczają podstawowe semantyczne kategorie zdaniowe, których badanie stanowi podstawę dla porównań, także porównań konfrontatywnych. Zaprezentowane zostały przykłady opracowania wybranych jednostek oraz wskazana skuteczność analizy, która pozwala ukazać różnice między zbiorami dopuszczalnych dla każdej z badanych klas struktur zdaniowych. Różnice te wynikają z charakteryzujących te klasy różnic semantycznych.

Keywords: semantic classes of verbs; syntax; lexicography; contrastive studies; Bulgarian language; Polish language; Russian language

Słowa kluczowe: klasy semantyczne czasowników; składnia; leksykografia; konfrontacja językowa; język bułgarski; język polski; język rosyjski

\footnotetext{
Małgorzata Korytkowska, Institute of Slavic Studies, Polish Academy of Sciences, Warsaw

Correspondence: mal_kor@wp.pl

The article is financed within the project Właściwości składniowe czasowników jako baza ich zintegrowanego opisu leksykograficznego (w perspektywie konfrontacji polsko-bułgarsko-rosyjskiej) [Syntacticfeatures of verbs as a basis for their integrated lexicographical description (from a Polish-Bulgarian-Russian contrastive perspective)], awarded for 2014-2017 by the National Centre for Science, Republic of Poland (grant no. 2013/11/B/HS2/03116).

Competing interests: The author has declared she has no competing interests.
} 